\title{
Heat shock protein 27 as a predictor of prognosis in patients admitted to hospital with acute COPD exacerbation
}

\begin{abstract}
Matthias Zimmermann ${ }^{1,2}$ (D) Denise Traxler ${ }^{1,3} \cdot$ Christine Bekos $^{1} \cdot$ Elisabeth Simader $^{1,4} \cdot$ Thomas Mueller $^{5} \cdot$ Alexandra Graf ${ }^{6}$ - Mitja Lainscak ${ }^{7,8} \cdot$ Robert Marčun $^{9} \cdot$ Mitja Košnik $^{9}$ • Matjaž Fležar ${ }^{9} \cdot$ Aleš Rozman $^{9} \cdot$ Peter Korošec $^{9}$. Walter Klepetko ${ }^{10} \cdot$ Bernhard Moser $^{10} \cdot$ Hendrik J. Ankersmit ${ }^{1,10}$
\end{abstract}

Received: 29 August 2019 / Revised: 15 October 2019 / Accepted: 25 November 2019 / Published online: 9 December 2019

(C) The Author(s) 2019

\begin{abstract}
Episodes of acute exacerbations are major drivers of hospitalisation and death from COPD. To date, there are no objective biomarkers of disease activity or biomarkers to predict patient outcome. In this study, 211 patients hospitalised for an acute exacerbation of COPD have been included. At the time of admission, routine blood tests have been performed including complete blood count, C-reactive protein, cardiac troponin T and NT-proBNP. Heat shock protein 27 (HSP27) serum concentrations were determined at time of admission, discharge and 180 days after discharge by ELISA. We were able to demonstrate significantly increased HSP27 serum concentrations in COPD patients at time of admission to hospital as compared to HSP27 concentrations obtained 180 days after discharge. In univariable Cox regression analyses, a HSP27 serum concentration $\geq 3098 \mathrm{pg} / \mathrm{mL}$ determined at admission was a predictor of all-cause mortality at 90 days, 180 days, 1 year and 3 years. In multivariable analyses, an increased HSP27 serum concentration at admission retained its prognostic ability with respect to all-cause mortality for up to 1year follow-up. However, an increased HSP27 serum concentration at admission was not an independent predictor of long-term all-cause mortality at 3 years. Elevated serum HSP27 concentrations significantly predicted short-term mortality in patients admitted to hospital with acute exacerbation of COPD and could help to improve outcomes by identifying high-risk patients.
\end{abstract}

Keywords Heat shock protein 27 . Chronic obstructive pulmonary disease $\cdot$ Acute exacerbation $\cdot$ Biomarker $\cdot$ Prognosis Mortality

$\begin{array}{ll}\text { Abbreviations } \\ \text { AECOPD } & \begin{array}{l}\text { Acute exacerbation of chronic obstructive pul- } \\ \text { monary disease }\end{array} \\ \text { CI } & \begin{array}{l}\text { Confidence interval } \\ \text { COPD }\end{array} \text { Chronic obstructive pulmonary disease } \\ \text { CRP } & \text { C-reactive protein } \\ \text { ELISA } & \text { Enzyme linked immunosorbent assay }\end{array}$

Hendrik J. Ankersmit

hendrik.ankersmit@meduniwien.ac.at

1 Christian Doppler Laboratory for Cardiac and Thoracic Diagnosis and Regeneration, Medical University of Vienna, Vienna, Austria

2 Department of Maxillofacial and Oral Surgery, Medical University of Vienna, Vienna, Austria

3 Division of Cardiology, Department of Internal Medicine II, Medical University of Vienna, Vienna, Austria

4 Division of Rheumatology, Department of Internal Medicine III, Medical University of Vienna, Vienna, Austria
GOLD Global Initiative For Chronic Obstructive Lung Disease

HR Hazard ratio

HSP Heat shock protein

IQR Interquartile range

LTOT Long-term oxygen therapy

N-terminal pro-brain natriuretic protein

5 Department of Clinical Pathology, Hospital of Bolzano, Bolzano, Italy

6 Center for Medical Statistics, Informatics and Intelligent Systems, Medical University of Vienna, Vienna, Austria

7 Division of Cardiology, General Hospital Murska Sobota, Murska Sobota, Slovenia

8 Faculty of Medicine, University of Ljubljana, Ljubljana, Slovenia

9 University Clinic of Pulmonary and Allergic Diseases Golnik, Golnik, Slovenia

10 Division of Thoracic Surgery, Department of Surgery, Medical University of Vienna, Vienna, Austria 
$\mathrm{NT}$ -

proBNP

cTnT Cardiac troponin $\mathrm{T}$

\section{Introduction}

Chronic obstructive pulmonary disease (COPD) is a major cause of chronic morbidity and mortality worldwide and its prevalence is still expected to rise (Adeloye et al. 2015; Huang et al. 2001). Although there has been substantial improvement in the understanding of COPD pathogenesis over the last years, existing treatments, such as bronchodilators or anti-inflammatory corticosteroids, have no proven disease modifying effect (Barnes and Adcock 2009).

A blunted regulatory $\mathrm{T}$ cell response to tobacco smoking has been identified in COPD patients (Barcelo et al. 2008; Lambers et al. 2009). Increased concentrations of CD28nullCD8+ cells have been shown (Hodge et al. 2011) and lymphocyte senescence seems to be associated with loss of molecular chaperone Hsp90 in CD28nullCD8+ T and NKT-like cells (Hodge et al. 2016). This loss is associated with steroid resistant pro-inflammatory lymphocytes and lung function in COPD (Hacker et al. 2009a).

The aim of current therapy is primarily to improve airflow, reduce dyspnea and prevent exacerbation (Barnes et al. 2003). Episodes of acute exacerbations are the major drivers of hospitalisation and death from COPD. There are no objective biomarkers of disease activity or biomarkers to guide therapeutic choices respectively to risk stratify patients for imminent exacerbations. Finding a reliable marker that identifies patients at risk for future hospitalisations in order to modify and optimise a patient's current therapy regime may significantly enhance prognosis among this group of patients. Regrettably, at this stage, there are no clinical tools or biomarkers to diagnose COPD exacerbations (Sin et al. 2015).

\section{Characteristics of an ideal biomarker}

A biomarker is a "characteristic that is objectively measured and evaluated as an indicator of normal biological processes, pathogenic processes, or pharmacologic responses to a therapeutic intervention" as defined by the National Institutes of Health Biomarkers Definitions Working Group in 1998 (Biomarkers Definitions Working Group 2001). In a clinical context, these characteristics are used in disease detection and monitoring of health states in individuals or across populations. They can be used to identify individuals with a disease or abnormal condition (diagnostic), as an indicator of disease prognosis (prognostic) or for prediction and monitoring of clinical response to an intervention (predictive). Ideally, a biomarker should be safe and easy to measure, accurate, reproducible across sex and age, modifiable with effective therapy, economical and most importantly should enable clinicians to better manage their patients (Sin et al. 2015; Hollander et al. 2017).

\section{Heat shock proteins in COPD}

Although there has been great effort in COPD biomarker discovery in recent years, clinical translation and implementation have not matched these efforts. Possible candidates that have been thoroughly investigated in COPD patients are heat shock proteins (HSPs). HSPs belong to a highly conserved protein family, which are classified according their molecular weight: some are induced in response to multiple stressful events to protect the cells while others are constitutively expressed. Initially, it was believed that HSPs are only present inside the cells. Interestingly, several groups recently reported the extracellular presence of HSPs (De Maio and Vazquez 2013). Secretion into the extracellular milieu during many pathological conditions suggests additional or novel functions of HSPs in addition to their intracellular properties. Extracellular HSPs are implicated in cell-cell communication, activation of immune cells, and promoting antiinflammatory and anti-platelet responses (Reddy et al. 2018; De et al. 2000).

The heat shock protein 27, which belongs to the group of small heat shock proteins, has been studied thoroughly in patients with COPD. Increased HSP27 serum concentrations in patients with COPD have been reported when compared with healthy non-smokers and smokers (Hacker et al. 2009b; Unver et al. 2016). Correlation of serum HSP27 concentrations with spirometry analysis and high-resolution computed tomography (HR-CT) revealed that HSP27 is an independent prognosticator of air trapping and emphysema in a study cohort of smokers (Jan Ankersmit et al. 2012). In regard to COPD exacerbations, no data on HSP27 serum concentrations exist.

The aim of this study was to investigate the role of serum HSP27 as a prognostic and predictive marker for all-cause mortality in patients hospitalised due to an episode of acute exacerbation of COPD (AECOPD) up to 3 years. Prognostication of patients with AECOPD could help to improve outcomes by identifying high-risk patients who might potentially benefit from intensive inpatient monitoring and treatment.

We therefore made a post hoc analysis in patients hospitalised due to acute exacerbation, which had been included in a controlled clinical trial to assess the effectiveness of discharge coordinator intervention compared to care as usual 
in patients with COPD. Retrospective serum HSP27 measurements were performed at time of hospitalisation, respectively, at later stages and correlated with survival data. Analytical performance characteristics have been determined earlier (Zimmermann et al. 2016).

\section{Materials and methods}

\section{Study subjects}

The study protocol has been approved by the National Ethics Committee of the Republic of Slovenia and is registered at ClinicalTrials.gov (NCT01225627). Informed and written consent was obtained from each subject included in the study and all clinical and laboratory tests were performed in accordance with the Declaration of Helsinki and the guidelines for Good Clinical Practice of the Medical University of Vienna. A detailed study protocol and main findings have been published previously (Farkas et al. 2011; Lainscak et al. 2013).

From the prospectively enrolled 253 participants, post hoc analyses were performed with 211 patients due to missing values or blood samples. All of them were admitted for AECOPD between November 2009 and December 2011 at the University Clinic of Pulmonary and Allergic Diseases Golnik, Slovenia. Inclusion and exclusion criteria have been described previously (Farkas et al. 2011). Blood serum samples were collected at admission to hospital, at time of discharge and 180 days after discharge. At the time of admission, routine laboratory parameters were determined including complete blood count, C-reactive protein (CRP), cardiac troponin $\mathrm{T}$ (cTnT) and (N-terminal pro-brain natriuretic peptide (NT-proBNP). CRP was measured with an immunoturbidimetric method, cTNT (high sensitivity) and NT-proBNP using an Electro-ChemiluminescenceImmunoassay (ECLIA, Elecsys 2010, Roche Diagnostics). Additionally, serum was obtained after centrifugation of blood samples and aliquots were stored at $80{ }^{\circ} \mathrm{C}$ until further testing.

Endpoint was all-cause mortality. Each patient was followed for 3 years (i.e., exactly 1095 days after admission to hospital) or until death if occurred earlier. Outcome data were available for all patients.

\section{Quantification of serum HSP27}

In a previously published work (Zimmermann et al. 2014), the R\&D ELISA DuoSet for total HSP27 (DYC1580, R\&D Systems, Minneapolis, MN, USA) showed high diagnostic accuracy in biochemical diagnosis of lung pathologies, when compared to other commercially available ELISA Kits. We therefore used the mentioned ELISA Kit to assess total serum HSP27 concentrations in one batch analysis according to the manufacturer's protocol.

\section{Determination of cutoff values}

The cutoff values of HSP27 serum concentrations at admission respectively age for Kaplan-Meier curve analysis and Cox proportional hazard models for mortality calculations were determined using Cutoff Finder version 2.1, a freely available $\mathrm{R}$ functions-based web application (Budczies et al. 2012), identifying values with highest diagnostic accuracy.

For cardiac biomarkers, the following cutoff values were used for survival analysis: age-adjusted values for NTproBNP (ng/L) (Januzzi Jr. et al. 2005) and single values of $14 \mathrm{ng} / \mathrm{L}$ for high sensitivity cTnT and $0.5 \mathrm{mg} / \mathrm{L}$ for CRP.

\section{Statistical analysis}

Statistical analysis was performed using IBM SPSS Statistics version 23 (SPSS Inc., Chicago, USA) and GraphPad Prism 6 software (GraphPad Software Inc., LA Jolla, CA, USA) was used for data visualisation. HSP27 serum concentrations were compared between different time points using Wilcoxon signed-rank test. Mann-Whitney $U$ test and Kruskal-Wallis test were used to compare non-parametric, unpaired variables. Kaplan-Meier curves and log-rank test were used to evaluate time to death for different subgroups (HSP27 high/low, NTproBNP high/low). Univariable Cox regression models were performed to identify potential influence factors. Multivariable Cox proportional hazard models were then used to further evaluate the prognostic ability of factors being significant in the univariable analysis. Results are expressed as hazard ratio (HR) with corresponding 95\% confidence intervals (CI). $P$ values were corrected for multiple testing.

Dunn correction was used for post hoc tests in multiple group comparison. All tests were performed in a two-sided manner. Data are presented as median \pm interquartile range (ICR). $P$ values equal or below 0.05 were considered as statistically significant.

\section{Results}

\section{Study population}

A total of 211 patients were included. Baseline characteristics are summarised in Table 1 . They were predominantly males (71\%) with advanced COPD (GOLD II-IV) and various comorbidities. All patients received COPD specific therapy according to guidelines. Median age was 72 (IQR, 64-77) years. Follow-up time was 1095 days. The number of deaths at 
Table 1 Patient characteristics $(N=211)$. Data are presented as median \pm interquartile range $(\mathrm{IQR})$ or number $(\%)$. HSP27 data are presented as median \pm interquartile range (IQR)

\begin{tabular}{|c|c|c|c|c|c|c|c|}
\hline & All patients & $\begin{array}{l}\text { HSP27 high } \\
\geq 3098 \mathrm{pg} / \mathrm{mL}\end{array}$ & $\begin{array}{l}\text { HSP27 low } \\
<3098 \mathrm{pg} / \mathrm{mL}\end{array}$ & $p$ value & $\begin{array}{l}\text { Survivors at } \\
3 \text { years }\end{array}$ & $\begin{array}{l}\text { Decedents at } \\
3 \text { years }\end{array}$ & $p$ value \\
\hline Number & 211 & 51 & 160 & & 115 & 96 & \\
\hline Age (median + IQR) & $72(64-77)$ & $76(72-81)$ & $70(62-76)$ & $p<0.001$ & $69(61-76)$ & $74(69-80)$ & $p<0.001$ \\
\hline Gender (male/female) & $150(71 \%) / 61(29 \%)$ & $35(69 \%) / 16(31 \%)$ & $115(72 \%) / 45(28 \%)$ & $p=0.723$ & $\begin{array}{c}74(64 \%) / 41 \\
(36 \%)\end{array}$ & $76(79 \%) / 20(21 \%)$ & $p=0.022$ \\
\hline GOLD class & & & & $p=0.156$ & & & $p=0.015$ \\
\hline GOLD 2 & $25(12 \%)$ & $3(6 \%)$ & $22(14 \%)$ & & $19(17 \%)$ & $6(6 \%)$ & \\
\hline GOLD 3 & $95(45 \%)$ & $28(55 \%)$ & $67(42 \%)$ & & $55(48 \%)$ & $40(42 \%)$ & \\
\hline GOLD 4 & $91(43 \%)$ & $20(39 \%)$ & $71(44 \%)$ & & $41(36 \%)$ & $50(52 \%)$ & \\
\hline LTOT & $47(22 \%)$ & $10(20 \%)$ & $37(23 \%)$ & $p=0.701$ & $19(17 \%)$ & $28(29 \%)$ & $p=0.032$ \\
\hline \multicolumn{8}{|c|}{ Concomitant diseases } \\
\hline Heart failure & $56(27 \%)$ & $19(37 \%)$ & $37(23 \%)$ & $p=0.067$ & $25(22 \%)$ & $31(32 \%)$ & $p=0.088$ \\
\hline $\begin{array}{l}\text { Arterial } \\
\text { hypertension }\end{array}$ & $51(43 \%)$ & $13(48 \%)$ & $38(42 \%)$ & $p=0.659$ & $25(40 \%)$ & $26(46 \%)$ & $p=0.578$ \\
\hline $\begin{array}{l}\text { Ischemic heart } \\
\text { disease }\end{array}$ & $17(14 \%)$ & $3(11 \%)$ & $14(15 \%)$ & $p=0.759$ & $8(13 \%)$ & $9(16 \%)$ & $p=0.794$ \\
\hline Arterial fibrillation & $19(16 \%)$ & $6(22 \%)$ & $13(14 \%)$ & $p=0.373$ & $7(11 \%)$ & $12(21 \%)$ & $p=0.209$ \\
\hline Diabetes mellitus & $27(23 \%)$ & $5(19 \%)$ & $22(24 \%)$ & $p=0.612$ & $12(19 \%)$ & $15(27 \%)$ & $p=0.385$ \\
\hline $\begin{array}{l}\mathrm{BMI}\left(\mathrm{kg} / \mathrm{m}^{2}, \text { median }\right. \\
\quad+\mathrm{IQR})\end{array}$ & $25.7(23.2-30.4)$ & $23.2(20.9-28.7)$ & $26.0(23.7-30.7)$ & $p=0.028$ & $25.4(23.5-30.1)$ & $26.5(22.9-30.9)$ & $p=0.946$ \\
\hline $\begin{array}{l}\text { Tiffenau index (\%, } \\
\text { median + IQR) }\end{array}$ & $41(32-52)$ & $45(35-55)$ & $40(31-51)$ & $p=0.279$ & $41(33-51)$ & $41(30-54)$ & $p=0.804$ \\
\hline $\begin{array}{l}\mathrm{CRP}(\mathrm{mg} / \mathrm{L}, \text { median } \\
\quad+\mathrm{IQR})\end{array}$ & $23.9(4.2-75.6)$ & $63.0(12.7-130.7)$ & $18.4(3.3-54.4)$ & $p=0.001$ & $18.9(3.474 .9)$ & $28.7(7.2-76.4)$ & $p=0.334$ \\
\hline $\begin{array}{l}\mathrm{cTnT}(\mathrm{ng} / \mathrm{L}, \text { median } \\
+ \text { IQR) }\end{array}$ & $0.0(0.0-18.0)$ & $17.0(0.0-50.0)$ & $0.0(0.0-9.5)$ & $p<0.001$ & $0.0(0.0-11.0)$ & $0.0(0.0-25.5)$ & $p=0.011$ \\
\hline $\begin{array}{c}\text { NT-proBNP (ng/L } \\
\text { median + IQR) }\end{array}$ & $471.2(138.7-1692.0)$ & $1292.0(432.5-4112.0)$ & $308.6(117.7-1197.5)$ & $p<0.001$ & $207.9(89.2-945.1)$ & $1018.5(324.5-2527.0)$ & $p<0.001$ \\
\hline $\begin{array}{l}\text { eGFR }(\text { CDK-EPI }) \\
\left(\mathrm{ml} / \mathrm{min} / 1.73 \mathrm{~m}^{2}\right. \\
\text { median }+\mathrm{IQR})\end{array}$ & $81.0(64.0-92.0)$ & $68.5(43.0-87.0)$ & $84.0(70.0-94.0)$ & $p<0.001$ & $81.0(65.0-92.0)$ & $80.5(63.0-92.0)$ & $p=0.835$ \\
\hline $\begin{array}{l}\text { HSP27—admission } \\
\text { (pg/ml, median + } \\
\text { IQR) }\end{array}$ & $2227(1560-3070)$ & $3615(3296-4344)$ & 1931 (1425-2384.9) & $p<0.001$ & 2205 (1481-2802) & $2257(1713-3217)$ & $p=0.225$ \\
\hline $\begin{array}{l}\text { HSP27_discharge } \\
\text { (pg/ml, median + } \\
\text { IQR) }\end{array}$ & $2037(1504-2836)$ & $2783(2269-3678)$ & $1857(1419-2521)$ & $p<0.001$ & $2002(1496-2836)$ & $2156(1510-2783)$ & $p=0.961$ \\
\hline $\begin{array}{l}\text { HSP27-180 days } \\
\text { (pg/ml, median + } \\
\text { IQR) }\end{array}$ & $1636(1333-2405)$ & $2169(1636-3605)$ & $1580(1305-2130)$ & $p=0.013$ & $1643(1355-2418)$ & 1621 (1332-1972) & $p=0.705$ \\
\hline
\end{tabular}

90 days after discharge was $14(6.5 \%), 26$ at 180 days (12.0\%), 40 after 1 year (18.4\%) and 95 after 3 years $(43.8 \%)$.

For survival analysis, cutoff values with highest diagnostic accuracy at time of admission have been identified using a cutoff finder (HSP27 $3098 \mathrm{pg} / \mathrm{ml}$ respectively age 72 years). Patients who had HSP27 concentrations above the defined cutoff were significantly older, kidney function was decreased and CRP and NT-proBNP concentrations were increased (Table 1).

\section{HSP27 in COPD patients}

Systemic HSP27 concentrations in healthy control patients were assessed in a previous study. Median HSP27 concentration was
$1482 \mathrm{pg} / \mathrm{ml}$ (IQR 1136-2071 pg/ml) in healthy non-smokers (Zimmermann et al. 2012).

Median HSP27 concentrations in our patient cohort was 2227 (IQR, 1560-3070) pg/ml at admission (211 patients), 2037 (IQR, 1504-2836) pg/ml at discharge (295 patients) and 1636 (IQR, 1333-2405) pg/ml at 180 days after discharge (113 patients). HSP27 concentrations at admission were significantly increased compared to 180 days after discharge (Table $1, p=0.02$ ).

HSP27 concentration at all time points was not significantly associated with GOLD classification. However, HSP27 concentrations correlated significantly with age at admission $(r=0.329, p<0.001)$ and discharge $(r=$ $0.244, p=0.001)$, but not 180 days after discharge $(r=$ $0.173, p=0.066$ ). 


\section{Survival analysis}

Outcome analysis using Kaplan-Meier survival curves are presented in Fig. 1. Patients with HSP27 concentrations above the cutoff showed a significantly increased risk of death $(p=0.02)$. The median survival time for patients with values above the cutoff was 838 [CI 95\% 1531095] as compared to 1095 [CI 95\% 626-1095] days $(p=0.007)$.

Potential risk factors for mortality were selected by univariable analyses. HSP27 demonstrates a significant predictive ability for short- and long-term mortality in the univariable analyses (Table 2, 3 year: HR 1.7, CI 95\% 1.1-2.6, $p=0.021$ ).

Variables that were significant in univariable analysis, such as age, gender, GOLD class, cTnT, and NT-proBNP, were included as adjusting covariates in multivariate analysis to identify potential factors for prediction of mortality. In multivariate Cox proportional hazard regression analysis, age, GOLD class and NTproBNP were significantly associated with an increased 3 year
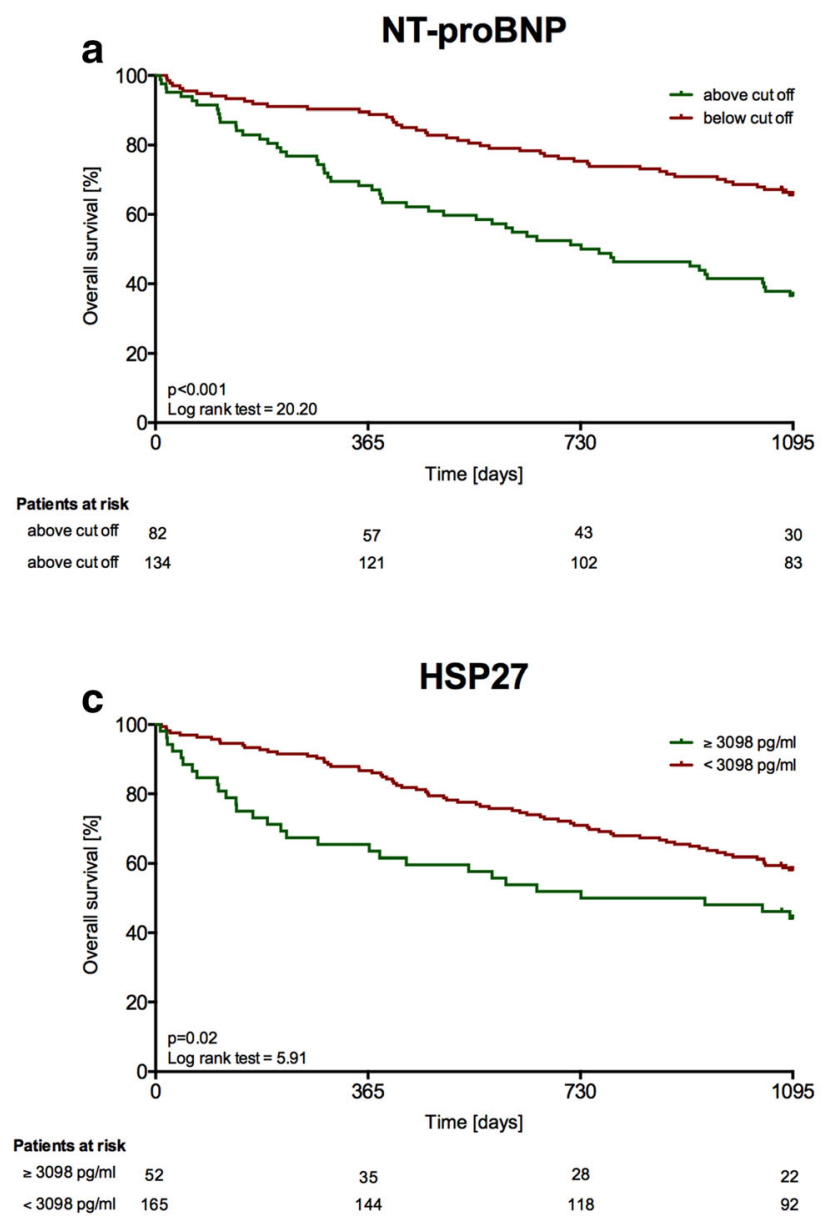

mortality (Table 3, Fig. 2). However, HSP27 did not remain significant in the model (using backward selection) for 3-year mortality, but it remained significant for short-term outcomes (Table 3, Fig. 2). A significant increased risk of death for patients with higher HSP27 values was found for 90 days (HR, 4.4; $95 \%$ CI, 1.5-12.8), 180 days (HR, 4.3; 95\% CI, 2.0-9.4) and 1 year (HR, 2.4; 95\% CI, 1.3-4.7) after discharge.

The combination of HSP27 and NT-proBNP in a KaplanMeier survival analysis showed a higher survival in the NTproBNP-low/HSP27-low group when compared with NTproBNP-low/HSP27-high after 2 years $(\log$-rank test $=5.373$, $p=0.02$ ).

\section{Association with other markers}

Elevated NT-proBNP and cTnT concentrations at admission were significantly associated with fatal outcome over the follow-up period (Fig. 1). Adjusted Cox proportional hazard models were built using cardiac biomarkers (Table 3). As CRP,

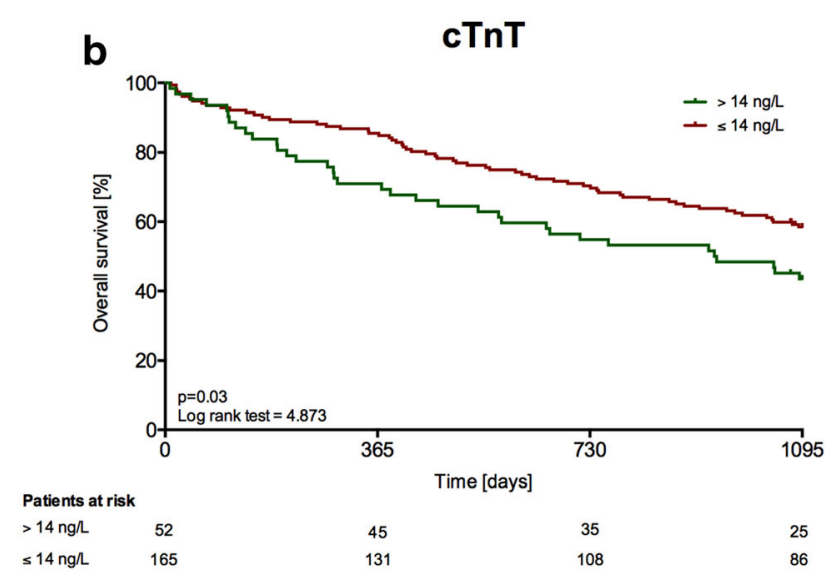

Fig. 1 Kaplan-Meier survival stratified by NT-proBNP (a), cTnT (b), HSP27 (c) and combined concentrations of HSP27 and NT-proBNP (d) at time of admission 
Table 2 Univariable Cox proportional hazards analysis for prognostic factor of outcome

\begin{tabular}{|c|c|c|c|c|c|c|c|c|}
\hline \multirow[t]{2}{*}{ Factor } & \multicolumn{2}{|c|}{ All-cause mortality at 90 days } & \multicolumn{2}{|c|}{ All-cause mortality at 180 days } & \multicolumn{2}{|c|}{ All-cause mortality at $1 \mathrm{a}$} & \multicolumn{2}{|c|}{ All-cause mortality at $3 \mathrm{a}$} \\
\hline & $\mathrm{HR}(\mathrm{CI})$ & $P$ & $\mathrm{HR}(\mathrm{CI})$ & $P$ & $\mathrm{HR}(\mathrm{CI})$ & $P$ & $\mathrm{HR}(\mathrm{CI})$ & $P$ \\
\hline Age $(\geq 72 a)$ & $1.3(0.5-3.7)$ & n.s. & $2.2(1.0-5.1)$ & n.s. & $2.7(1.3-5.4)$ & 0.003 & $1.9(1.3-2.9)$ & 0.001 \\
\hline Gender (male) & $0.7(0.2-2.4)$ & n.s. & $0.9(0.4-2.1)$ & n.s. & $0.9(0.5-1.9)$ & n.s. & $0.6(0.4-1.0)$ & 0.043 \\
\hline GOLD (I, II, III) & $2.0(0.8-4.9)$ & n.s. & $2.3(1.2-4.7)$ & 0.017 & $1.8(1.1-3.0)$ & 0.024 & $1.6(1.2-2.2)$ & 0.002 \\
\hline $\mathrm{CRP}(\geq 0.5 \mathrm{mg} / \mathrm{L})$ & $4.5(0.6-35)$ & n.s. & $2.7(0.8-9.1)$ & n.s. & $1.6(0.7-3.6)$ & n.s. & $1.4(0.9-2.3)$ & n.s. \\
\hline $\operatorname{cTnT}(\geq 14$ ng/L) & $1.0(0.3-3.1)$ & n.s. & $1.6(0.7-3.5)$ & n.s. & $2.1(1.1-4.0)$ & 0.017 & $1.6(1.0-2.4)$ & 0.029 \\
\hline NT-proBNP (age-adjusted) & $1.7(0.6-4.7)$ & n.s. & $2.3(1.1-5.1)$ & 0.032 & $3.3(1.7-6.4)$ & $<0.001$ & $2.4(1.6-3.6)$ & $<0.001$ \\
\hline HSP27 ( $\geq 3098$ pg/ml) & $4.4(1.5-12.8)$ & 0.006 & $4.1(1.9-8.9)$ & $<0.001$ & $3.1(1.7-5.7)$ & $<0.001$ & $1.7(1.1-2.6)$ & 0.021 \\
\hline
\end{tabular}

cTnT and NT-proBNP have already been identified as markers that predict prognosis in COPD patients after an episode of acute exacerbation (Marcun et al. 2012; Brekke et al. 2008; Hoiseth et al. 2011; Medina et al. 2011; Chang et al. 2011), we have correlated HSP27 concentrations with those markers. At admission, serum concentrations of HSP27 correlated significantly with CRP $(r=0.240, p<0.001)$, cTnT $(r=0.353, p<0.001)$ and NT-proBNP $(r=0.429, p<0.001)$.

Due to its small size, renal elimination of HSP27 is conceivable and we could show a significant association of HSP27 serum concentrations with kidney function. HSP27 correlated with eGFR $(r=-0.375, p<0.001)$.

\section{Discussion}

COPD exacerbations can be life threatening and are the major drivers for hospitalisation of COPD patients. Furthermore, they are believed to contribute to permanent lung changes and permanent decrements in lung function.

In the current study, we were able to demonstrate significantly increased serum HSP27 concentrations in COPD patients at time of admission to hospital due to an episode of acute exacerbation and a decrease of these concentrations after decline of acute symptoms and discharge from hospital. Furthermore, we identified a HSP27

\section{0 days}

a

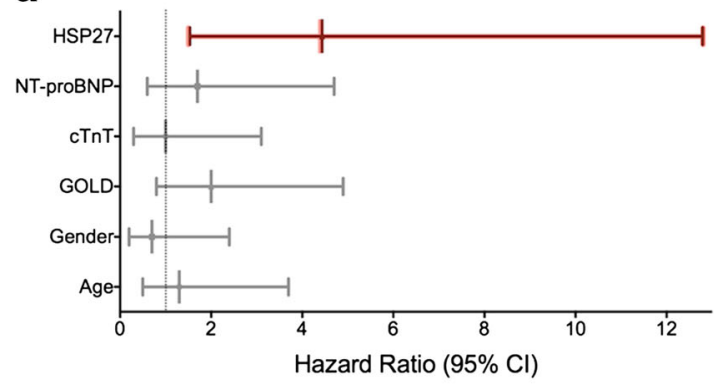

1 year

C

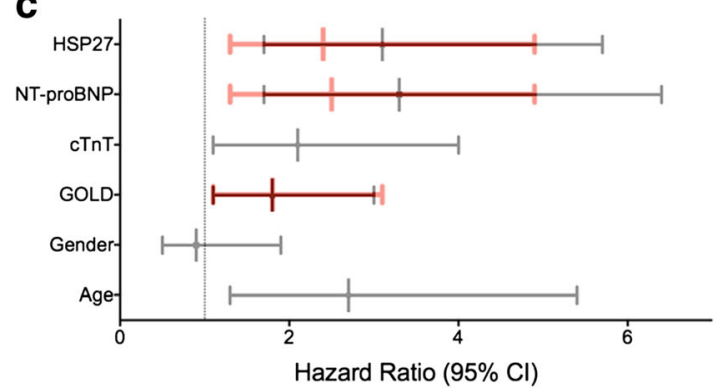

b

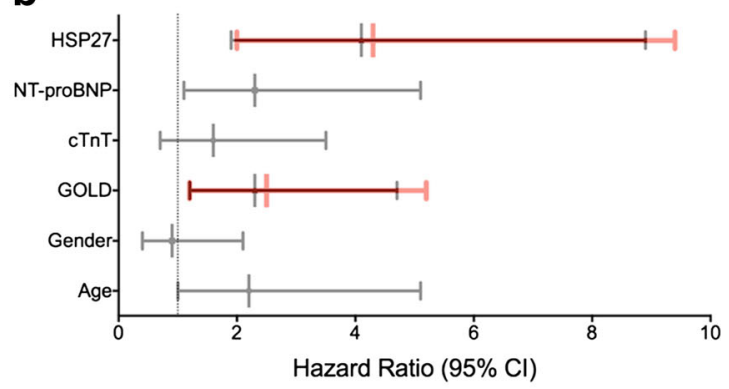

3 years

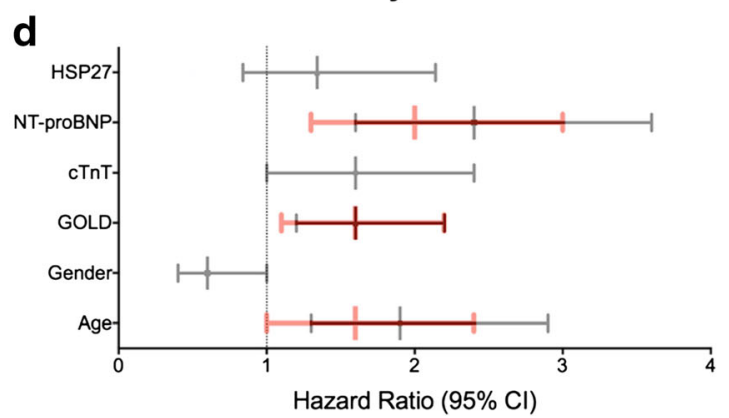

Fig. 2 Hazard ratios (HR) and 95\% confidence interval (CI) in univariable (grey bar) and multivariable (red bar) Cox regression analysis after 90 days (a), 180 days (b), 1 year (c) and 3 years (d). Variables remaining in the model after multivariable analyses are presented in red 
Table 3 Multivariable Cox proportional hazards analysis with backward selection for prognostic factors of outcome

\begin{tabular}{|c|c|c|c|c|c|c|c|c|}
\hline \multirow[t]{2}{*}{ Factor } & \multicolumn{2}{|l|}{90 days } & \multicolumn{2}{|l|}{180 days } & \multicolumn{2}{|l|}{$1 \mathrm{a}$} & \multicolumn{2}{|l|}{$3 a$} \\
\hline & $\mathrm{HR}(\mathrm{CI})$ & $P$ & $\mathrm{HR}(\mathrm{CI})$ & $P$ & $\mathrm{HR}(\mathrm{CI})$ & $P$ & $\mathrm{HR}(\mathrm{CI})$ & $P$ \\
\hline Age $(\geq 72 a)$ & - & n.s. & - & n.s. & - & n.s. & $1.6(1.0-2.4)$ & 0.047 \\
\hline Gender (male) & - & n.s. & - & n.s. & - & n.s. & - & n.s. \\
\hline GOLD (I, II, III) & - & n.s. & $2.5(1.2-5.2)$ & 0.013 & $1.8(1.1-3.1)$ & 0.031 & $1.6(1.1-2.2)$ & 0.008 \\
\hline $\operatorname{cTnT}(\geq 14 \mathrm{ng} / \mathrm{L})$ & - & n.s. & - & n.s. & - & n.s. & - & n.s. \\
\hline NT-proBNP (age-adjusted) & - & n.s. & - & n.s. & $2.5(1.3-4.9)$ & 0.009 & $2.0(1.3-3.0)$ & 0.001 \\
\hline HSP27 ( $\geq 3098$ pg/ml) & $4.4(1.5-12.8)$ & 0.006 & $4.3(2.0-9.4)$ & $<0.001$ & $2.4(1.3-4.7)$ & 0.008 & - & n.s. \\
\hline
\end{tabular}

serum cutoff value serving as significant predictor for both short- and long-term mortality using Kaplan-Meier curve analyses and univariate Cox proportional hazard models. We were able to confirm previous findings that NT-proBNP and cTnT predict outcome of these patients.

After adjusting the model for other markers that are known to be associated with mortality in COPD, only HSP27 retained its prognostic performance for shortterm mortality.

However, we were not able to significantly correlate serum HSP27 in patients with manifest COPD exacerbation and previous COPD staging according to the GOLD classification (Hacker et al. 2009b).

Although there have been great advances in the understanding of COPD pathogenesis over the last years, biomarker discovery and implementation into the realm of clinics remains challenging. By now, most biomarkers failed to make it beyond the discovery stage. This may be due to the heterogeneity of disease pathogenesis. COPD is not a single entity; airflow limitation is caused by highly variable molecular processes (Lange et al. 2015).

If there is a benefit in serum HSP27 detection in COPD patients still remains unclear. Although HSP27 showed statistical trends to serve as a biomarker in previous works, the diagnostic role remains a matter of debate, as several other conditions and comorbidities may affect serum concentrations. Increased concentrations of circulating HSP27 are reported in different cancers, including lung cancer (Zimmermann et al. 2012), breast cancer (Fanelli et al. 1998; Banerjee et al. 2011), hepatocellular carcinoma (Gruden et al. 2013), pancreatic carcinoma (Liao et al. 2009; Melle et al. 2007), gastric adenocarcinoma (Huang et al. 2010), endometrial cancer and leukaemia. Lastly, elevated concentrations of circulating HSP27 have been observed in patients with cardiovascular disease (Jozefowicz-Okonkwo et al. 2009; Park et al. 2006; Zhang et al. 2017; Jin et al. 2014; Heidari-Bakavoli et al. 2012), multiple sclerosis (Ce et al. 2011), diabetes
(Gruden et al. 2008; Jakhotia et al. 2018) or renal injury (Jakhotia et al. 2018; Musial and Zwolinska 2012; Lebherz-Eichinger et al. 2012). All these observations culminate to suggest that HSP27, when found its way to the extracellular milieu, seems to have manifold functions, similar as reported from its intracellular presence. Secreted HSP27 plays an instrumental role in cell-to-cell communication, signalling, immunity and inflammation (Reddy et al. 2017).

Despite lacking disease specificity, current observations suggest that HSP27 serum concentrations can predict disease progress and short-term mortality after COPD exacerbation. Prognostication with HSP27 determination could help to improve outcomes by identifying high-risk patients who might potentially benefit from intensive monitoring and early referral for advanced therapies. It could therefore be a useful tool for clinical decisionmaking at time of admission.

\section{Conclusions}

Can HSP27 concentrations be used as a predictive and prognostic marker in COPD patients? To obtain a satisfactory answer to this question, further data on a larger population are needed. Results from this initial discovery experiment should be replicated in other cohorts to ensure stability and generalisability of data. More prospective clinical trials are needed to establish optimal cutoff values for survival predictions.

The major limitation of the current study is the fact, that no intervention apart from standard care treatment was performed. So one can only hypothesise that HSP27 serum concentrations can guide therapeutic decisions and enable clinicians to better manage their patients with AECOPD. Furthermore, serum concentrations of HSP27 in healthy individuals may be affected by large intraindividual variation, and assays to date have lacked appropriate standardisation (Zimmermann et al. 2016). 
Acknowledgements Open access funding provided by Medical University of Vienna.

Open Access This article is licensed under a Creative Commons Attribution 4.0 International License, which permits use, sharing, adaptation, distribution and reproduction in any medium or format, as long as you give appropriate credit to the original author(s) and the source, provide a link to the Creative Commons licence, and indicate if changes were made. The images or other third party material in this article are included in the article's Creative Commons licence, unless indicated otherwise in a credit line to the material. If material is not included in the article's Creative Commons licence and your intended use is not permitted by statutory regulation or exceeds the permitted use, you will need to obtain permission directly from the copyright holder. To view a copy of this licence, visit http://creativecommons.org/licenses/by/4.0/.

\section{References}

Adeloye D, Chua S, Lee C, Basquill C, Papana A, Theodoratou E, Nair H, Gasevic D, Sridhar D, Campbell H, Chan KY, Sheikh A, Rudan I (2015) Global and regional estimates of COPD prevalence: systematic review and meta-analysis. J Glob Health 5(2):020415

Banerjee S, Lin CF, Skinner KA, Schiffhauer LM, Peacock J, Hicks DG, Redmond EM, Morrow D, Huston A, Shayne M, Langstein HN, Miller-Graziano CL, Strickland J, O'Donoghue L, De AK (2011) Heat shock protein 27 differentiates tolerogenic macrophages that may support human breast cancer progression. Cancer Res 71(2):318-327

Barcelo B, Pons J, Ferrer JM, Sauleda J, Fuster A, Agusti AG (2008) Phenotypic characterisation of T-lymphocytes in COPD: abnormal CD4+CD25+ regulatory T-lymphocyte response to tobacco smoking. Eur Respir J 31(3):555-562

Barnes PJ, Adcock IM (2009) Glucocorticoid resistance in inflammatory diseases. Lancet. 373(9678): 1905-1917

Barnes PJ, Shapiro SD, Pauwels RA (2003) Chronic obstructive pulmonary disease: molecular and cellular mechanisms. Eur Respir J 22(4):672-688

Biomarkers Definitions Working Group (2001) Biomarkers and surrogate endpoints: preferred definitions and conceptual framework. Clin Pharmacol Ther 69(3):89-95

Brekke PH, Omland T, Holmedal SH, Smith P, Soyseth V (2008) Troponin T elevation and long-term mortality after chronic obstructive pulmonary disease exacerbation. Eur Respir J 31(3):563-570

Budczies J, Klauschen F, Sinn BV, Gyorffy B, Schmitt WD, DarbEsfahani S, Denkert C (2012) Cutoff finder: a comprehensive and straightforward Web application enabling rapid biomarker cutoff optimization. PLoS One 7(12):e51862

Ce P, Erkizan O, Gedizlioglu M (2011) Elevated HSP27 levels during attacks in patients with multiple sclerosis. Acta Neurol Scand 124(5):317-320

Chang CL, Robinson SC, Mills GD, Sullivan GD, Karalus NC, McLachlan JD, Hancox RJ (2011) Biochemical markers of cardiac dysfunction predict mortality in acute exacerbations of COPD. Thorax. 66(9):764-768

De Maio A, Vazquez D (2013) Extracellular heat shock proteins: a new location, a new function. Shock. 40(4):239-246

De AK, Kodys KM, Yeh BS, Miller-Graziano C (2000) Exaggerated human monocyte IL-10 concomitant to minimal TNF-alpha induction by heat-shock protein 27 (Hsp27) suggests Hsp27 is primarily an antiinflammatory stimulus. J Immunol 165(7):3951-3958

Fanelli MA, Cuello Carrion FD, Dekker J, Schoemaker J, Ciocca DR (1998) Serological detection of heat shock protein hsp27 in normal and breast cancer patients. Cancer Epidemiol Biomark Prev 7(9): 791-795
Farkas J, Kadivec S, Kosnik M, Lainscak M (2011) Effectiveness of discharge-coordinator intervention in patients with chronic obstructive pulmonary disease: study protocol of a randomized controlled clinical trial. Respir Med 105(Suppl 1):S26-S30

Gruden G, Bruno G, Chaturvedi N, Burt D, Schalkwijk C, Pinach S, Stehouwer CD, Witte DR, Fuller JH, Perin PC (2008) Serum heat shock protein 27 and diabetes complications in the EURODIAB prospective complications study: a novel circulating marker for diabetic neuropathy. Diabetes. 57(7):1966-1970

Gruden G, Carucci P, Lolli V, Cosso L, Dellavalle E, Rolle E, Cantamessa A, Pinach S, Abate ML, Campra D, Brunello F, Bruno G, Rizzetto M, Perin PC (2013) Serum heat shock protein 27 levels in patients with hepatocellular carcinoma. Cell Stress Chaperones 18(2):235241

Hacker S, Lambers C, Pollreisz A, Hoetzenecker K, Lichtenauer M, Mangold A, Niederpold T, Hacker A, Lang G, Dworschak M, Vukovich T, Gerner C, Klepetko W, Ankersmit HJ (2009a) Increased soluble serum markers caspase-cleaved cytokeratin-18, histones, and ST2 indicate apoptotic turnover and chronic immune response in COPD. J Clin Lab Anal 23(6):372-379

Hacker S, Lambers C, Hoetzenecker K, Pollreisz A, Aigner C, Lichtenauer M, Mangold A, Niederpold T, Zimmermann M, Taghavi S, Klepetko W, Ankersmit HJ (2009b) Elevated HSP27, HSP70 and HSP90 alpha in chronic obstructive pulmonary disease: markers for immune activation and tissue destruction. Clin Lab 55(1-2):31-40

Heidari-Bakavoli AR, Sahebkar A, Mobara N, Moohebati M, Tavallaie S, Rahsepar AA, Kazemi A, Alavi MS, Ghayour-Mobarhan M, Ferns GA (2012) Changes in plasma level of heat shock protein 27 after acute coronary syndrome. Angiology. 63(1):12-16

Hodge G, Mukaro V, Reynolds PN, Hodge S (2011) Role of increased CD8/CD28(null) T cells and alternative co-stimulatory molecules in chronic obstructive pulmonary disease. Clin Exp Immunol 166(1): 94-102

Hodge G, Roscioli E, Jersmann H, Tran HB, Holmes M, Reynolds PN, Hodge S (2016) Steroid resistance in COPD is associated with impaired molecular chaperone Hsp90 expression by pro-inflammatory lymphocytes. Respir Res 17(1):135

Hoiseth AD, Neukamm A, Karlsson BD, Omland T, Brekke PH, Soyseth $\mathrm{V}$ (2011) Elevated high-sensitivity cardiac troponin T is associated with increased mortality after acute exacerbation of chronic obstructive pulmonary disease. Thorax. 66(9):775-781

Hollander Z, DeMarco ML, Sadatsafavi M, McManus BM, Ng RT, Sin DD (2017) Biomarker development in COPD: moving from $\mathrm{P}$ values to products to impact patient care. Chest. 151(2):455-467

Huang S, Lichtenauer UD, Pack S, Wang C, Kim AC, Lutchman M, Koch CA, Torres-Cruz J, Huang SC, Benz EJ Jr, Christiansen H, Dockhorn-Dworniczak B, Poremba C, Vortmeyer AO, Chishti AH, Zhuang Z (2001) Reassignment of the EPB4.1 gene to 1p36 and assessment of its involvement in neuroblastomas. Eur J Clin Investig 31(10):907-914

Huang Q, Ye J, Huang Q, Chen W, Wang L, Lin W, Lin J, Lin X (2010) Heat shock protein 27 is over-expressed in tumor tissues and increased in sera of patients with gastric adenocarcinoma. Clin Chem Lab Med 48(2):263-269

Jakhotia S, Sivaprasad M, Shalini T, Reddy PY, Viswanath K, Jakhotia K, Sahay R, Sahay M, Reddy GB (2018) Circulating levels of Hsp27 in microvascular complications of diabetes: prospects as a biomarker of diabetic nephropathy. J Diabetes Complicat 32(2):221-225

Jan Ankersmit H, Nickl S, Hoeltl E, Toepker M, Lambers C, Mitterbauer A, Kortuem B, Zimmermann M, Moser B, Bekos C, Steinlechner B, Hofbauer H, Klepetko W, Schenk P, Dome B (2012) Increased serum levels of HSP27 as a marker for incipient chronic obstructive pulmonary disease in young smokers. Respiration. 83(5):391-399

Januzzi JL Jr, Camargo CA, Anwaruddin S, Baggish AL, Chen AA, Krauser DG, Tung R, Cameron R, Nagurney JT, Chae CU, Lloyd- 
Jones DM, Brown DF, Foran-Melanson S, Sluss PM, LeeLewandrowski E, Lewandrowski KB (2005) The N-terminal proBNP investigation of dyspnea in the emergency department (PRIDE) study. Am J Cardiol 95(8):948-954

Jin C, Phillips VL, Williams MJ, van Rij AM, Jones GT (2014) Plasma heat shock protein 27 is associated with coronary artery disease, abdominal aortic aneurysm and peripheral artery disease. Springerplus. 3:635

Jozefowicz-Okonkwo G, Wierzbowska-Drabik K, Kasielski M, Trzos E, Goraca A, Nowak D, Kasprzak J, Krzeminska-Pakula M (2009) Is Hsp27 a marker of myocardial ischaemia? Kardiol Pol 67(9):947952

Lainscak M, Kadivec S, Kosnik M, Benedik B, Bratkovic M, Jakhel T, Marcun R, Miklosa P, Stalc B, Farkas J (2013) Discharge coordinator intervention prevents hospitalizations in patients with COPD: a randomized controlled trial. J Am Med Dir Assoc 14(6):450 e451450 e 456

Lambers C, Hacker S, Posch M, Hoetzenecker K, Pollreisz A, Lichtenauer M, Klepetko W, Ankersmit HJ (2009) T cell senescence and contraction of $\mathrm{T}$ cell repertoire diversity in patients with chronic obstructive pulmonary disease. Clin Exp Immunol 155(3):466-475

Lange P, Celli B, Agusti A, Boje Jensen G, Divo M, Faner R, Guerra S, Marott JL, Martinez FD, Martinez-Camblor P, Meek P, Owen CA, Petersen H, Pinto-Plata V, Schnohr P, Sood A et al (2015) Lungfunction trajectories leading to chronic obstructive pulmonary disease. N Engl J Med 373(2):111-122

Lebherz-Eichinger D, Ankersmit HJ, Hacker S, Hetz H, Kimberger O, Schmidt EM, Reiter T, Horl WH, Haas M, Krenn CG, Roth GA (2012) HSP27 and HSP70 serum and urine levels in patients suffering from chronic kidney disease. Clin Chim Acta 413(1-2):282-286

Liao WC, Wu MS, Wang HP, Tien YW, Lin JT (2009) Serum heat shock protein 27 is increased in chronic pancreatitis and pancreatic carcinoma. Pancreas. 38(4):422-426

Marcun R, Sustic A, Brguljan PM, Kadivec S, Farkas J, Kosnik M, Coats AJ, Anker SD, Lainscak M (2012) Cardiac biomarkers predict outcome after hospitalisation for an acute exacerbation of chronic obstructive pulmonary disease. Int J Cardiol 161(3):156-159

Medina AM, Marteles MS, Saiz EB, Martinez SS, Laiglesia FR, Rodriguez JA, Perez-Calvo JI (2011) Prognostic utility of NTproBNP in acute exacerbations of chronic pulmonary diseases. Eur J Int Med 22(2):167-171

Melle C, Ernst G, Escher N, Hartmann D, Schimmel B, Bleul A, Thieme H, Kaufmann R, Felix K, Friess HM, Settmacher U, Hommann M, Richter KK, Daffner W, Taubig H, Manger T et al (2007) Protein profiling of microdissected pancreas carcinoma and identification of HSP27 as a potential serum marker. Clin Chem 53(4):629-635
Musial K, Zwolinska D (2012) Hsp27 as a marker of cell damage in children on chronic dialysis. Cell Stress Chaperones 17(6):675-682

Park HK, Park EC, Bae SW, Park MY, Kim SW, Yoo HS, Tudev M, Ko YH, Choi YH, Kim S, Kim DI, Kim YW, Lee BB, Yoon JB, Park JE (2006) Expression of heat shock protein 27 in human atherosclerotic plaques and increased plasma level of heat shock protein 27 in patients with acute coronary syndrome. Circulation. 114(9):886893

Reddy VS, Madala SK, Trinath J, Reddy GB (2017) Extracellular small heat shock proteins: exosomal biogenesis and function. Cell Stress Chaperones

Reddy VS, Madala SK, Trinath J, Reddy GB (2018) Extracellular small heat shock proteins: exosomal biogenesis and function. Cell Stress Chaperones 23(3):441-454

Sin DD, Hollander Z, DeMarco ML, McManus BM, Ng RT (2015) Biomarker development for chronic obstructive pulmonary disease. From discovery to clinical implementation. Am J Respir Crit Care Med 192(10):1162-1170

Unver R, Deveci F, Kirkil G, Telo S, Kaman D, Kuluozturk M (2016) Serum heat shock protein levels and the relationship of heat shock proteins with various parameters in chronic obstructive pulmonary disease patients. Turk Thorac J 17(4):153-159

Zhang H, Jia K, Sun D, Yang M (2017) Protective effect of HSP27 in atherosclerosis and coronary heart disease by inhibiting reactive oxygen species. J Cell Biochem

Zimmermann M, Nickl S, Lambers C, Hacker S, Mitterbauer A, Hoetzenecker K, Rozsas A, Ostoros G, Laszlo V, Hofbauer H, Renyi-Vamos F, Klepetko W, Dome B, Ankersmit HJ (2012) Discrimination of clinical stages in non-small cell lung cancer patients by serum HSP27 and HSP70: a multi-institutional case-control study. Clin Chim Acta 413(13-14):1115-1120

Zimmermann M, Mueller T, Dieplinger B, Bekos C, Beer L, Hofbauer H, Dome B, Ankersmit HJ (2014) Circulating heat shock protein 27 as a biomarker for the differentiation of patients with lung cancer and healthy controls-a clinical comparison of different enzyme linked immunosorbent assays. Clin Lab 60(6):999-1006

Zimmermann M, Traxler D, Simader E, Bekos C, Dieplinger B, Lainscak M, Ankersmit HJ, Mueller T (2016) In vitro stability of heat shock protein 27 in serum and plasma under different pre-analytical conditions: implications for large-scale clinical studies. Ann Lab Med 36(4):353-357

Publisher's note Springer Nature remains neutral with regard to jurisdictional claims in published maps and institutional affiliations. 